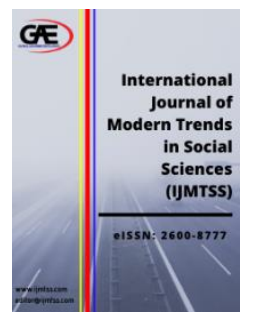

\author{
INTERNATIONAL JOURNAL OF \\ MODERN TRENDS IN \\ SOCIAL SCIENCES \\ (IJMTSS) \\ www.ijmtss.com
}

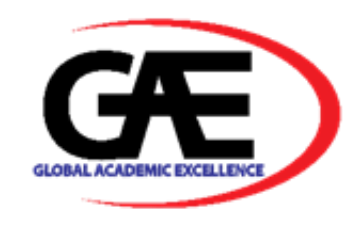

\title{
A REVIEW OF CULTURE AND COMMUNICATION ORIENTATION AMONG MALAY WORKERS TOWARDS SILENCE BEHAVIOUR TENDENCY
}

\author{
Robe'ah Yusuf $^{*}$, Azhar Hj Wahid ${ }^{2}$, Sasigaran Moneyam³ ${ }^{3}$ Siti Asma' Mohd Rosdi ${ }^{4}$ \\ 1 Centre for Languages and General Studies, Universiti Pendidikan Sultan Idris, Malaysia \\ Email: robe_ah@pbmpu.upsi.edu.my \\ 2 Faculty of Languages and Communication, Universiti Pendidikan Sultan Idris, Malaysia \\ Email: azhar@fbk.upsi.edu.my \\ 3 Centre for Languages and General Studies, Universiti Pendidikan Sultan Idris, Malaysia \\ Email: sasigaran@pbmpu.upsi.edu.my \\ 4 Faculty of Management and Economics, Universiti Pendidikan Sultan Idris, Malaysia \\ Email: sitiasma@fpe.upsi.edu.my \\ * Corresponding Author
}

\section{Article Info:}

\section{Article history:}

Received date:01.06.2020

Revised date: 30.06 .2020

Accepted date: 16.11.2020

Published date: 03.03.2021

\section{To cite this document:}

Yusuf, R., Hj Wahid, A., Moneyam, S., \& Rosdi, S. A. M. (2021). A Review of Culture and Communication Orientation Among Malay Workers Towards Silence Behaviour Tendency. International Journal of Modern Trends in Social Sciences, 4 (15), 13-20.

DOI: $10.35631 / I J M T S S .415002$

This work is licensed under CC BY 4.0

\begin{abstract}
:
This article discusses the review of the concept of culture, value, and belief in the Malay community. The focus is on the Malay workers working in a German organisation in Malaysia. Previous studies show that there are communication and cultural gaps when workers from various races and countries working in a multinational organisation. Asian communities mainly Malay, practices collective values such as cooperation among members, care about others' dignities and, silence due to some factors which indirectly affect communication orientation while working with other races. These practices are different from the European community who observes individualistic values. Typically, the Malays work together in voicing opinions or maintaining long-term relationships. In this article, the authors discuss the groupthink theory, which may influence the workers' behaviours in organisations and decision making.
\end{abstract}

Keywords:

Culture, Groupthink, Europe, Asian, Collective 


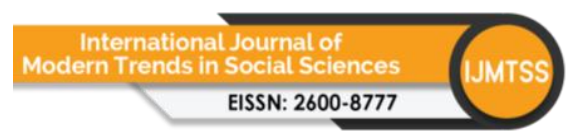

Volume 4 Issue 15 (March 2021) PP. 13-20

DOI 10.35631/IJMTSS.415002

\section{Introduction}

Working in a multinational organisation which is different from their own culture is a significant challenge for Malay workers. For example, Malays working in German organisations in Malaysia. This situation leads to work dissatisfactory, in conducive communication environment and lower productivity (Robe'ah, Ezhar, Jusang \& Mohd Nizam, 2016).The previous study shows that Malaysian face difficulties in dealing with foreign workers (Rou \& Kim, 2018) which indicates that cross-cultural communication usually creates conflicts in interpretation and meaning.

In the organisation study, silence behaviour is a situation in which the workers deny information-sharing in the organisation (Erenler, 2010). Failure in information dissemination leads to organisational loss due to collective silence, such as no cooperation and problem discussion (Fazilah \& Zafir, 2005). According to Cheung, Peng and Wong (2014), Asian countries like Malaysia and Indonesia are collectively in the cultural dimension that is of indirect message delivery and non-verbal communication. Community-closeness creates softer communication in expressing feelings, subtle, and silence using body language and to take care of others' feelings (Robe'ah et al., 2016).

\section{Cultural Concept}

Authors would like to provide a review of the culture, and its concept before continues to discuss the cultural roles in influencing communication. A culture that exists in acculturation is due to the unity of two cultures. Both cultures meet, tolerate and complement one another. However, the features of each culture do not change, remove existing aspects or nature of the cultures. The unity between two different cultures will form a harmonious situation, which is known as compatibility (Rou \& Kim, 2018).

In the context of cultural differences and diversity, something that is judged to be good or right in one culture is not necessarily considered good and right in another. Something that can is deemed to be appropriate and inappropriate in one culture is not necessarily recognised as relevant in another culture. For example, in America, Germany and northern France, make a circle of thumb and forefinger, with the other three fingers standing as a signal to say "okay" or "good". However, in Southern France, the sign means "none" or "empty". In the city of Paris, the signal means "you are worthless", or the signal "immoral" invitation. As for the Greeks, it means "rude" or "insult" in Brazil (Mulyana, 2002).

A culture also exists through assimilation, the combination process and unification of ethnics from various cultures to form a group with similar culture and identity. Absolute assimilation leads to complete abolition of cultural and identity differences. This concept represented with the formula $\mathrm{A}+\mathrm{B}+\mathrm{C}=\mathrm{A}$. A means the dominant group, while $\mathrm{B}$ and $\mathrm{C}$ represent minority ethnics groups (Shamsul Amri, 2012).

Accommodation is a process in which each ethnic group accepts and respects the norms and values of other ethnic groups while retaining theirs. The formula for this concept is $\mathrm{A}+\mathrm{B}+$ $C=A+B+C . A, B$ and C refers to the cultures. Shamsul Amri (2012) asserts that multiple ethnics groups living harmoniously and respecting each other. In the central administration, each ethnic group will have their representatives in the economic and education sectors, and dependent on each other. This concept widely practised in Malaysia in which each ethnic groups free to practice their cultures harmoniously. 


\section{Communication Orientation}

DOI 10.35631/IJMTSS.415002

Communication orientation is a communication practice by individual communities (Shamsul Amri, 2012). Communication orientation encounters in the context of low and high culture may lead to communication barrier (Hofstede, 1984). Nevertheless, the authors will only discuss the communication perspective of cultural practices of Malay workers working in a multinational organisation that contribute to silence behaviour. Authors discuss the analysis model or integrated cultural dimension based on Hofstede (1984) cultural dimension as in Diagram 1 which focuses on the communication orientation of low and high context culture influenced by individual value versus the collective. Diagram 1 shows the five cultural dimensions by Hofstede (1984)

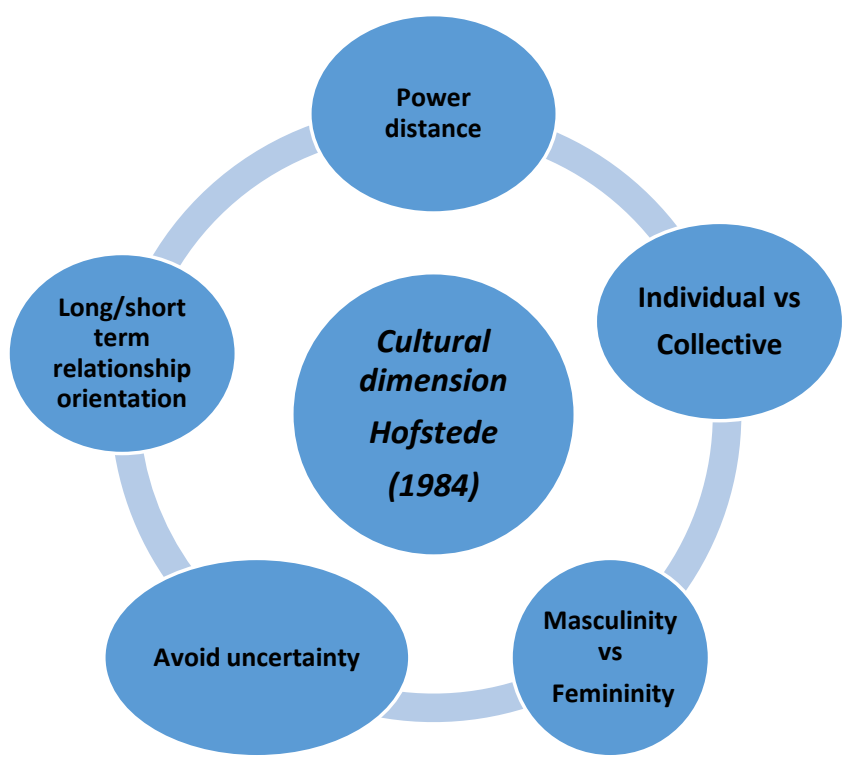

Figure 1. Five Cultural Dimensions, Hofstede (1984)

\section{Literature Review}

Liu (2012) asserts that Asian countries like Malaysia and Indonesia have a harmonious collective culture that is indirect message delivery and non-verbal communication. Community-closeness creates softer communication in expressing feelings, subtle, and silence using body language and taking care of other's feelings. (Liu, 2012; Zulkefli, 2010).

This issue opts to be studied because the encounters of communication orientation in low and high cultural contexts may lead to communication barrier (Hofstede, 1984). 


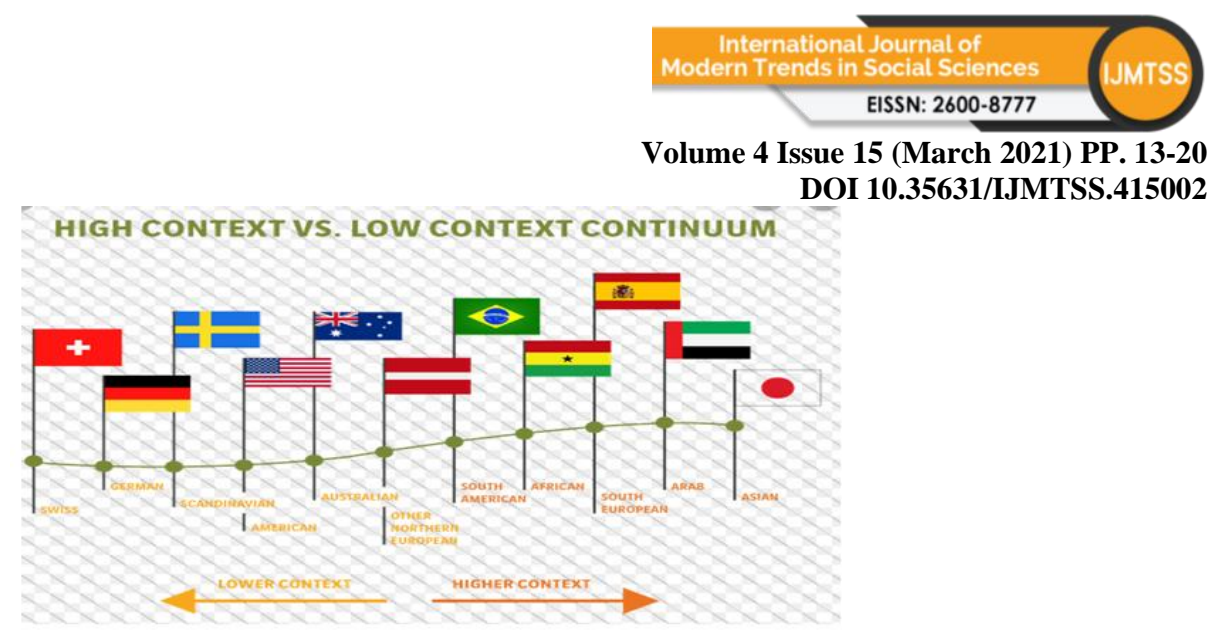

Figure 2: High-Low Cultural Contexts by T. Hall (1976)

Source: Cross-Cultural Institute (Facebook): Beyond Culture

According to Nikolaou, Vakola and Bourantas (2011), the concept of silence refers to the workers' behaviours which is due to failure in expressing feelings, opinions, concerns and sense of belonging towards the job and other activities in the organisation.

Values and attitudes of Malay workers usually reflect the Malay culture and traditional values, namely collectivism which focuses on relationships between humans, lower uncertainty avoidance, and outer-directed orientation. In contrast, the European organisation culture focuses on organisation, higher uncertainty avoidance and inner-directed orientation (Rou \& Kim, 2018).

Malay workers are tolerant and flexible. They will say 'nothing' which mean 'it's okay, don't care, don't worry', despite having problems and challenges. The expression 'nothing' reflects the attitudes and values of Malay workers who are open-hearted or easy-going in which this word usually used in their daily conversations (Rou \& Kim, 2018).

To conduct detailed observation on silence behaviour in organisation in Malaysia, the cultural researcher should be more open towards various factors in Asian workers considering the collectivity of the communities (Cheung, Peng \& Wong, 2014). Therefore, research on the organisation in Asia and West should be viewed in different perspectives, especially in term of cultures, religions, beliefs, values and teachings (Cheung, Peng \& Wong, 2014). According to Erenler (2010), the issues involved in the research between Asia and West includes those produced and developed by the members such as language, ways of thinking, arts, law, and religions. Erenler (2010) also describes that the values are passed down through generations, not genetics.

Karande and Singhapakdi (2002) stress that the Malay community in Malaysia do not likes confrontation and are polite. Generally, the Malays express their wishes in a subtle way to maintain their dignity (Shamsul Amri, 2012). Nevertheless, Malaysians comprise of various races practices values like respecting elders, leaders, uphold the dignity, maintain hierarchy and harmony (Fazilah\&Zafir, 2005).

For instance, most of the previous studies feature Malaysian communities, particularly the Malays for not being straightforward (Rou \& Kim, 2018; ShamsulAmri, 2012; Fazilah\&Zafir, 2005). According to Hassan and Che Su (2013), there are six dimensions to measure the communication culture of Malays in the workplace, namely respect and respecting, discussion, maintain dignity, decency, concern and collective negotiation which 


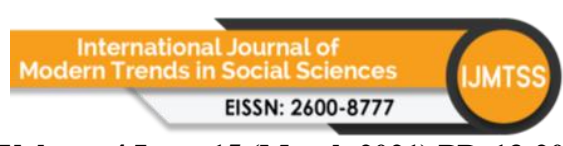

Volume 4 Issue 15 (March 2021) PP. 13-20

DOI 10.35631/IJMTSS.415002

contains 23 items. Structural equation analysis used to test the developed model. Results of the structural equation analysis show that all six dimensions can be the determinant for work satisfactory among workers (Hassan \& Che Su, 2013). Rou and Kim (2018) state that one of the characteristics of Malay workers is their attitude of patience or tolerance with their surroundings, although the situation does not favour them. Malay workers stress on selfcontrol and emotion rather than try to control the situation and surrounding. The social values of Malay workers are due to the influence of Islamic beliefs that focuses on patience as one of the human quality based their belief on fate. Since Islam emphasis on patience in Muslim, Malay workers are also patience towards all matters, including about others and unpleasant situations (Rou \& Kim, 2018).

\section{Groupthink Theory and Malay Community Practices}

Groupthink is generally a way of thinking of a group of people, which represents a person's model of thinking when they are in a cohesive group. It occurs when all members of the group trying to think to be unanimous. Therefore, the decision-making process is made by evaluating any suggestions and alternatives and putting pressure on members to adhere to and prevent irrelevant ideas. When there is a majority opinion, one's critical ability is no longer significant (Berger, 2010).

The Groupthink Theory (Janis, 1972) is related to the statement by Morrison and Milliken (2000) that there are norms in organisations that hinder subordinates from expressing sensitive views to the top management. Groupthink Theory (Janis, 1982) explains about the phenomenon in organisations which systematically hamper information delivery to the top. This situation is a collective phenomenon in which members of the organisation concerns about the unity in the organisation to maintain harmony and focuses on the good news to the organisation (Berger, 2010). Berger (2010) states that psychologically, the community try to deter from saying negative views because afraid it is against the norm, laws and can break up the group. The Groupthink Syndrome can happen in an organisation with strong unity and can give strong effects to the organisation, especially in the field of security, strategic and military (Zulkefli, 2010). The examples of the impact of groupthink are, the mistake of the White House in underestimating attack by Japanese force on Pearl Harbour, President Truman's decision to attack North Koreas, misjudgement by President Johnson during the Vietnam War and Cuban crisis mission (Janis, 1982). Zulkefli (2010) concludes that groupthink syndrome can be identified in an organisation when the following situations occur:

(i) Workers practice silence when facing an uncertain situation.

(ii) Silence is considered an agreement to the decision made.

(iii) Members do not express disagreement because of the fear of repercussions for going against the views of the leader.

This situation portrays the togetherness developed from the think-group attitude based on Groupthink theory which in hand with the study conducted by Rose, (2011). Rose (2011) relates how the think-group attitude can influence the study on management and decisionmaking in an organisation. However, Dyne, Ang and Botero (2003) claims that in management, there are norms in an organisation that hinder subordinates from expressing sensitive issues to the top management, and workers tend to be silence. Zulkefli (2010) relates to the community practices that contribute to the organisational practices related to the Groupthink theory (Janis, 1972). This theory describes the phenomenon in an organisation that systematically hinder information delivery to the top that happens collectively. It is a Copyright (C) GLOBAL ACADEMIC EXCELLENCE (M) SDN BHD - All rights reserved 
collective phenomenon in which the members in the organisation emphasis on the unity in the organisation to maintain harmony and focuses on good news about the organisation and avoid from expressing negative matters for fear of going against the norm and break the group. Groupthink only happens in an organisation that has strong unity. The diagram shows how the collective values of the community, especially the Asian community, which result in silence attitude phenomenon (Lim, 2001).

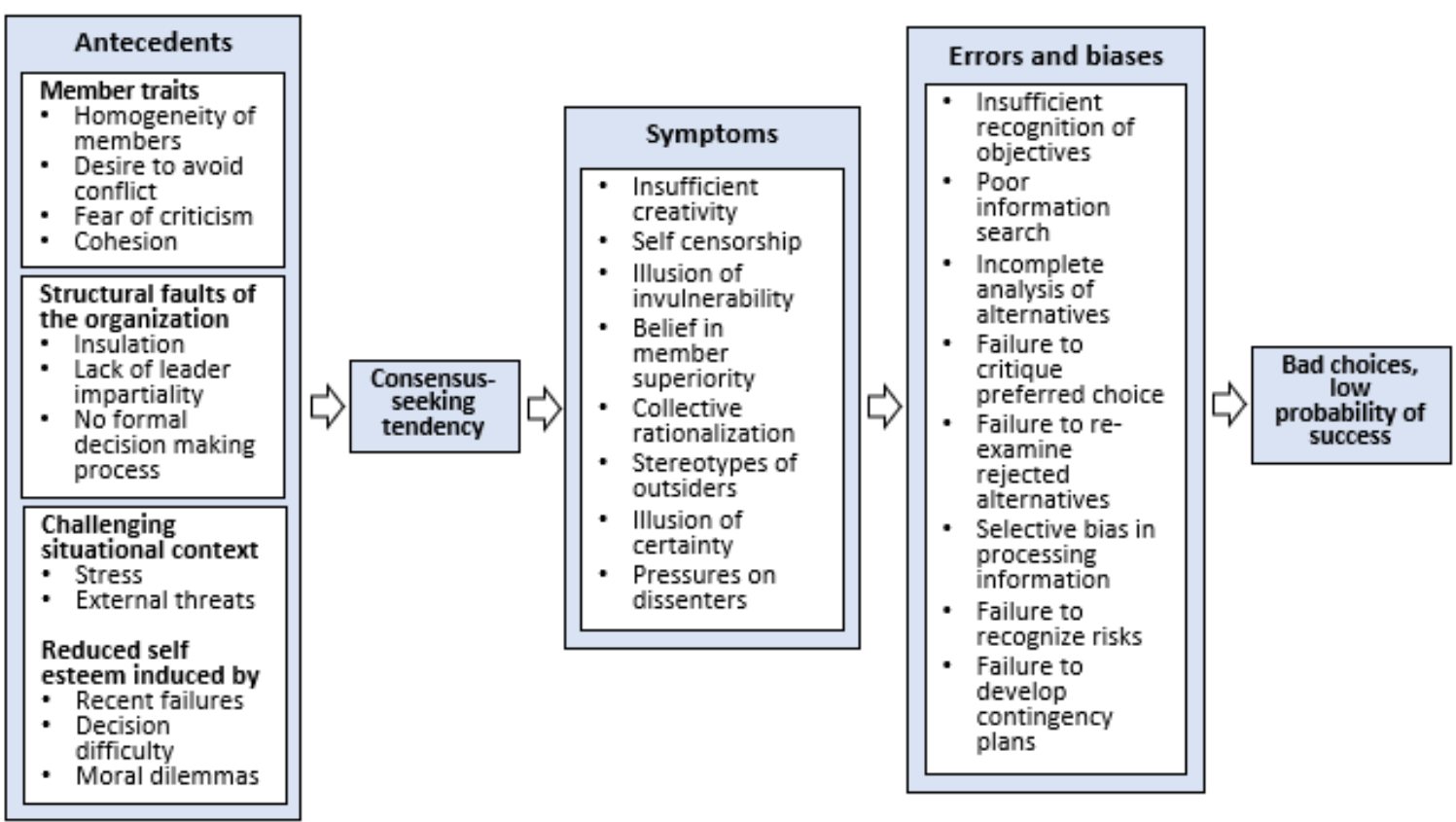

Figure 3. Collective values in Groupthink Theory

Source: Schematic of the Groupthink Model (Irving Janis, 1972)

The characteristics are related to the research findings of Hofstede G. (1984) in terms of collective values dimension. Malaysian culture is known for a culture that forms collective cooperation. This culture can clearly be seen in the attitude of Malay workers who are tolerant and open towards the various situation as a group. The element relates the attitude of cooperation among Malay workers and portrays their values of unity, solidarity and follow the voice of the majority in a group and based on the needs of the situation and surrounding (Lim, 2001).

Therefore, it can be concluded that the framework of Groupthink thinking, according to Janis (1972), is as follows:

(i) The high level of agreement of community members causes an opinion to be accepted because they do not want to be excluded and want to be taken as members of a collective group.

(ii) A leader is a dominant role holder and usually displays every advantage and character he possesses

(iii) A provocative situation is a situation when there is concern among members of the community in conveying their opinions. 


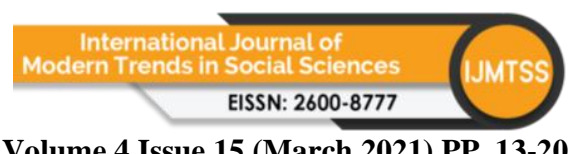

Volume 4 Issue 15 (March 2021) PP. 13-20

DOI 10.35631/IJMTSS.415002

It is because there is pressure from outside that can cause anxiety and fear due to the risk of failure.

As a result, this matter leads to Malay workers who are tolerant and flexible. They will say 'nothing' which mean 'it's okay, don't care, don't worry', despite having problems and challenges for following the majority voice. The expression 'nothing' reflects the attitudes and values of Malay workers who are often giving up and refuse to give opinions openly (Rou \& Kim, 2018).

\section{Conclusion}

Based on the above discussion, it can be concluded that there will be conflicts in understanding other parties when working together in an organisation. This conflict is due to clashes of cultures, practices and differences in communication orientation. Understanding each other is vital for mutual works and the benefits of the organisations. This statement is in line with Ko (2005), who found that there is leadership influence on group decision-making. Obeying the instructions, respecting and accepting the decision of the leader is cultural norm of the Malays. Asian Malays are said to represent the culture of collectiveness for the survival of its society.

In this matter, refuse to express views are not due to clashes of culture and lack of understanding of cultural diversity. Thus, this discussion recommends that understanding and being tolerance are ways to solve the problem when working together at a multinational organisation. The study conducted by Fazilah and Zafir (2005) affirms that the Malaysian community is collectivism culturally, less masculine, wide power distance and lower uncertainty avoidance. This finding is closely related to the theory of Groupthink (Janis, 1972), which is about how a group of people can make minimal and tolerant consensus to reduce conflict among members. Based on the above discussion, cultural characteristics clearly show relativism which does not only hold to the principles and rules but is flexible and open to various situations. If the Malay workers do not make decision cooperatively, they will face impacts like feeling threatened, stressed and not safe when working with workers from a different culture. The foreign culture sometimes involves ordering, forcing, monitoring and harsh in facing cross-cultural conflicts (Rou \& Kim, 2007).

In conclusion, the community that practices collective values will always know the main opinion and will follow the main idea just because not want to be removed from the group due to different views. If the surrounding community is not in favour of their opinion, they will remain silent. They will indicate that we agree with the general opinion that happens in the reputation management of an organisation (Bodor, 2012). Being quiet can influence the readiness to express views and only in a particular situation which lead to silence behaviour.

\section{References}

Berger, M. (2010). Making waves or keeping calm? Analyzing the institutional cultural of family courts through the lens of social psychology Groupthink theory. Law \& Psychology Review, 34, 55-90.

Bodor, T. (2012). The Issue of Timing and Opinion Congruity in Spiral of Silence Research: Why Does Research Suggest Limited Empirical Support for the Theory? International Journal of Public Opinion Research, 24(3), 269-286. doi:10.1093/ijpor/eds016 


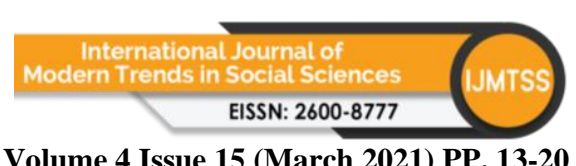

Volume 4 Issue 15 (March 2021) PP. 13-20

DOI 10.35631/IJMTSS.415002

Cheung, M.; Peng, K.K.; Wong, C.S. (2014). Supervisor Attribution of Subordinate's Organizational Citizenship Behavior Motives. Journal of Management. Psychol. Vol. 29, 922-937.

Dyne, L. V., Ang, S., \&Botero, I. C. (2003). Conceptualizing employee silence and employee voice as multidimensional constructs. Journal of Management Studies, 40(6), 13591392.

Erenler, Esra. (2010). The Relationship of Silence Behavior of the Employees between Some Personal and Organizational Traits: A Field Survey in Tourism Sector, (Unpublished Ph.D Dissertation), Hacettepe University, Institute of Social Sciences, Ankara.

Fazilah Mohd Hasan \& Zafir Mohamed Makhbul. (2005). The issues of corporate culture in the organization management. Prosiding Seminar Kebangsaan Pembangunan Sumber Manusia 176-186.

Hassan Abu Bakar \& Che Su Mustaffa. (2013). Organizational communication in Malaysia organizations: Incorporating cultural values in communication scale. Corporate Communications: An International Journal, 18(1), 87-109.

Hofstede, G. (1984). Culture Consequences, International Differences in Work-related Values. CA: Sage Publications.

Janis, I.L. (1972). Victims of Groupthink, Houghton Mifflin, Boston, MA.

Janis, I.L. (1982). Groupthink, Houghton Mifflin, Boston, MA.

Karande, K., Rao, C.P., \& Singhapakdi, A. (2002). Moral philosophies of marketing managers: A comparison of American, Australian and Malaysian cultures. European Journal of Marketing, 36(8), 768-954.

Ko, A. S. O., (2005). Organizational communications in Hong Kong: a cultural approach to groupthink. Corporate Communications: An International Journal, 10(4), 351-357

Lim, L. (2001). Work related values of Malays and Malaysian Chinese. International Journal of Cross-cultural Management, 1, 209-226.

Liu, Y. (2012). The Perceived Importance of Cultural Priority for Global Business Operations: A Study of Malaysian Managers. Research and Practice in Human Resource Management,20(1), 57-65.

Mulyana Deddy (2002). Mengapa dan Untuk Apa Kita Mempelajari Komunikasi Antar Budaya, Dalam: Komunikasi Antar Budaya, Panduan Berkomunikasi Dengan OrangOrang Berbeda Budaya, Editor: Deddy Mulyana dan Jalaluddin Rakhmat, Bandung: Remaja Rosdakarya.

Nikalaou,I.,Vakola,M.and Bourantas,D.(2011). The role of silence on employees' attitudes 'the day after' a merger. Personnel Review, Vol. 40 No. 6, pp. 723-741.

Robe'ah Yusuf, Ezhar Tamam, Jusang Bolong, Mohd Nizam Osman. (2016). The Relationship between Interpersonal Attraction and Personality with Silence among Malaysian Subordinates in Selected German Organizations. Journal of Islamic Social Sciences and Humanities, Vol.7 (May) 2016 :pp 147-168.

Rose, J. (2011). Diverse perspectives on the Groupthink theory : a literary review. Emerging Leadership Journeys, 4(1), 37-57.

Rou, S.Y \& Kim, K.H. (2018).Variations in the Asian Collectivistic Working Culture in Intercultural Collaboration: A Case of a South Korean Company in Malaysia. Pertanika J. Soc. Sci. \& Hum. 26 (3): 1633 - 1650.

Shamsul Amri. (2012). Modul Hubungan Etnik. Bangi: Institut Kajian Etnik, UKM.

Zulkefli Ismail. (2010). Perilaku membisu dalam organisasi Tentera Darat Malaysia. (Tesis Doktor Falsafah yang tidak diterbitkan). Sintok: Universiti Utara Malaysia 